\section{Law and medicine}

\author{
Fernando Cano-Valle
}

Academia Nacional de Medicina de México, Ciudad de México, Mexico
Georg Jellinek, who was born in Leipzig in 1851 and died in Heidelberg in 1911 and whose education included studies in law, philosophy, geography and art history, expressed that: ${ }^{1}$

...The dogmatic form of legal standards can only be explained by means of the art of the jurist, an art that consists in abstracting regulations from the legal phenomena, and in deducing the consequences that they imply. The dogmatics of law is irreplaceable, but the exclusive use thereof is insufficient to cover the multiple aspects of the life of the State, hence the researcher needs the other disciplines.

With no doubt, Jellinek was inspired by John Locke (1632-1704), a British physician and representative of English empiricism, who laid the basic principles of liberal constitutionalism.

Over the years, prominent Mexican jurists have thus understood the relationship between law and medicine. Dr. Mario de la Cueva -a renowned jurist, doctor and rector of the National Autonomous University of Mexico with a democratic vocation- was also interested in John Locke's academic thinking. He once expressed that "the State and the law are real life creations", in the sense that the legal system will govern the behavior of men. He invited contemporary jurists to generate better health conditions for Mexican society by the Mexican State, based upon the law. Jorge Carpizo used to point out: "the State begins where democracy ends". Sergio García Ramírez, Héctor Fix Zamudio, Fix Fierro and Diego Valadés, among other distinguished jurists, have made important contributions to Mexican society and health, and have done it emphatically from the academic field.

In particular, the National Academy of Medicine of Mexico has been enriched by the incorporation into the heart of this institution of Minister José Ramón Cossío Díaz, whose interdisciplinary social-democratic approach will undoubtedly continue to be a formidable pillar in order for the Academy to have more impact on better laws around health. We need to publish, and publish at the intersection between law and medicine, particularly considering that we have an official journal that, revitalized with great social content will be a powerful tool to analyze the changes that appear in sight.

By empowering Congress to legislate on health, the regulatory scaffolding has a coordination regime between authorities at different levels of government based on the framework law, i.e., the General Statute of Health. The large number of regulations implies a great change in Mexico's health system; it requires that the State prevents human rights abuse and proposes a positive behavior that ensures the right to health. It is pertinent mentioning that health is currently over-regulated, which negatively affects the provision of services.

At the end of November 2018, the tenure of the National Academy of Medicine of Mexico board of directors for the 2017-2018 period was concluded. Two intense years of sustained progress and total commitment of our Chairman, Dr. Armando Mansilla Olivares, and the splendid results delivered by all executives of the institution will allow the incoming board of directors to receive a strengthening push towards a qualitative change in a wave of health policies renewal.

The new board of directors is chaired by a remarkable scientist. For the first time in 155 years of life, the Mexican woman will be present in the Academy in a foreground of great significance, Dr. Teresita Corona Vázquez, accompanied by collaborators of new generations who open great expectations. They will be in line with the World Health Organization and the Pan American Health Organization, in a health system characterized by its segmentation both in financing and in
Gac Med Mex. 2019;155:1-2

Contents available at PubMed www.gacetamedicademexico.com 
access to services, with a large health service-providing private sector that requires regulation.

Currently, health faces demographic, political-administrative, financial and scientific-technological problems, which point to the need for the Mexican State to take on the challenge of modifying its modus operandi with the purpose to act more efficaciously, efficiently, consistently and transparently in a complex reality. ${ }^{2}$

In this new stage, the National Academy of Medicine of Mexico will run across the structural inadequacies in the administration of fragmented services, and the costs that this represents, which are unparalleled and whose growth has been exponential over the last 30 years, with the consequence of a growing chronic morbidity, an upturn in infectious processes, an increase of addictions in the population and mental illnesses that remain without an efficient, comprehensive approach.

The agenda for change requires an essential redesign, able to clearly laying out scenarios in advance and thereby avoiding belatedly facing the problems. There is no doubt that the first challenge our health system must face is to achieve equity between citizens, solving accumulated lags and unacceptable inequality. Poverty is deprivation of capabilities; health indicators are deficient in the poorest and, paradoxically, more is invested or spent in the private sector.

We require that health specialists in the Mexican health system, particularly doctors, acquire a new centrality. The doctor is the real guarantor of the human right to health, and therefore he/she must be provided with all the tools and means to make this task possible. ${ }^{3}$

In addition to seeking health services universal coverage, it is also important to clearly separate them from other social security and development services and end with the dispersion of resources thereto allocated. Although health is intimately linked to social security issues, such as pensions and other social development affairs, in the current distribution of resources the health issue is not concentrated, which causes inefficiency.

Diego Valadés has pointed out that there is a principle according to which "ignorance of the law does not exempt its compliance". This way, nobody can claim not having complied with a provision due to the fact of not knowing it. However, it happens that, on the contrary, many times there are rights that are not exercised because they are not known. The participation of the National Academy of Medicine of Mexico is necessary in order to emphasize that the right to health is an unpostponable human right.

\section{References}

1. Jellinek G. La Declaración de los Derechos del Hombre y del Ciudadano. España. Comares; 2009. p. 10.

2. Salazar-Ugarte P, Oropeza-García A, Romero-Tellaeche JA, editores. La responsabilidad el porvenir. Tomo I. México: El Colegio de México, Instituto de Investigaciones Jurídicas UNAM, Instituto para el Desarrollo Industrial y el Crecimiento Económico; 2018. p. 457.

3. Mansilla-Olivares A, Cano-Valle F, Treviño-Becerra A, et al. Declaratoria de la Academia Nacional de Medicina de México. El futuro de la seguridad social y la asistencia médica en México. México: Academia Nacional d Medicina de México; 2018. p. 9 